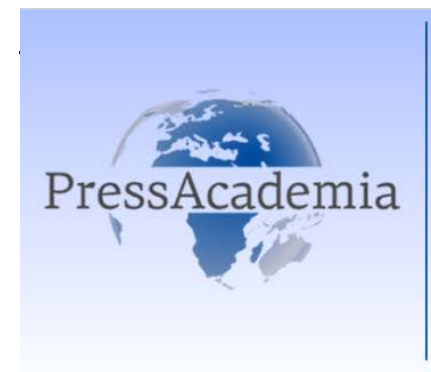

Press Academia Procedía

Global Business Research Congress (GBRC), May 26-27, 2016, Istanbul, Turkey.

\title{
BURNOUT OF EMPLOYEES IN THE SERVICE INDUSTRY AND AN APPLICATION IN ESKIŞEHIR
}

\section{DOI: 10.17261/Pressacademia.2016118637}

\author{
Huseyin Gurbuz ${ }^{1}$, Murat Karapinar ${ }^{2}$ \\ ${ }^{1}$ Eskişehir Osmangazi Üniversitesi, hgurbuz2002@gmail.com \\ ${ }^{2}$ Milli Eğitim Bakanlı̆̆ı, muratkarapinar@hotmail.com
}

\begin{abstract}
The foundation of people lies in the service industry. Service professionals, especially those in one-to-one communication with customers; both represent the business and the service that performed. It is important to remember that the importance of manpower in the service industry. Because a human being is again providing services and serving the people's quality of service is affected when faced with various difficulties are psychological in nature and the quality of service can also vary. That research on we made in sectors shopping face to face, and in the same location, working hours and the variability of the holidays, workload difficulties arising from, reduces the efficiency of the charge of lack of business who, being cool work and reveal the sense of burnout. This study is aimed to determine the employees Burnout levels in electronics and white goods, clothing, food and beverage and other retail sectors that located in the province of Eskisehir. Maslach Burnout Inventory was applied to the employees and 720 employees Burnout levels were measured.According to the research results, employees' emotional exhaustion and depersonalization subscales, have high level of burnout whereas the personal accomplishment dimension has medium level burnout were found. The relationship between demographic characteristics and sub dimensions of burnout, examined by $\mathrm{t}$ test, $\mathrm{F}$ test and multiple regression analysis.
\end{abstract}

Keywords: Burnout, Maslach Burnout Inventory, service Industry

JEL Codes: D23, M12

\section{HIZMET SEKTÖRÜNDE ÇALIŞANLARIN TÜKENMIŞLiĞi VE ESKIŞEHIR iLINDE BIR UYGULAMA}

\section{ÖZET}

Hizmet sektöründe insan temeli yatmaktadır. Hizmet sektöründe çalışanlar özellikle birebir müşteri ile iletişim içinde olanlar; hem yapılan hizmeti hem de ait olunan işletmeyi temsil ederler. Hizmet sektöründe insan gücünün önemini unutmamak gerekir. Çünkü hizmeti sağlayan da yine bir insandır ve hizmetin kalitesi hizmet veren kişinin karşılaştığı çeşitli zorluklarla etkilenmekte zaman içerisinde psikolojik yapısı ve hizmetin kalitesi değişkenlik gösterebilmektedir. Araştırmasını yaptığımız sektörlerde alışverişin yüz yüze ve aynı mekânda olması, çalışma saatlerinin ve izin günlerinin değişkenlik göstermesi, iş yoğunluğundan kaynaklanan zorluklar, ücretlerin yetersizliği iş görenlerin verimini düşürmekte, işten soğutmakta ve tükenmişlik duygusunu ortaya çıkarmaktadır. Bu çalışma Eskişehir ilinde bulunan elektronik ve beyaz eşya, giyim, yiyecek-içecek ve diğer perakendecilik sektörlerinde çalışan iş görenlerin tükenmişlik düzeylerinin belirlenmesi amacıyla yapılmıştır. Maslach Tükenmişlik Envanteri kullanılarak 720 çalışana anket uygulanmış ve çalışanların tükenmişlik düzeyleri ölçülmüştür. Anket sonuçlarına göre; iş görenlerin duygusal tükenme, duyarsızlaşma alt boyutlarında yüksek düzeyde tükenmişlik, kişisel başarı alt boyutunda ise orta düzeyde tükenmişlik yaşadıkları görülmüştür. Tükenmişliğin alt boyutları ile demografik özellikler arasındaki ilişki t testi, $F$ testi ve çoklu regresyon analizi ile incelenmiştir.

Anahtar Kelimeler: Tükenmişlik, Maslach Tükenmişlik Envanteri, hizmet sektörü JEL Kodları: D23, M12 


\section{GiRiş}

Hizmet sektöründe, insanın önemli olduğu ve yüz yüze çalışılan alanlarda sıklıkla görülen tükenmişlik sendromu çalışanların yıpranıp psikolojik ve bedensel olarak rahatsızlanmalarına, çalışanların işten ayrılmasına veya atılmasına, hizmetin kalitesinin düşmesine, maddi ve manevi zararlara, sosyal problemlere neden olmaktadır. Tükenmişlik sendromuna yakalanmış insanlar işinden nefret ediyor, işini savsaklıyor, hizmet verdiği kişilere ve onların sorunlarına karşı duyarsızlaşıyor. İş yerinde, çalışanlar ve yöneticilerle, evde eşi ve çocuklarıyla çatışıyor, kişide güven kaybı artıyor, kendini yetersiz ve değersiz hissediyor, enerji ve odaklanma sorunu yaşıyor, kilo alma ve uyku problemleri, baş ağrısı, sırt ağrısı, mide ağrısı gibi fiziksel sorunlar da ortaya çıkabiliyor. Bunun sonucunda işten ayrılma ve intihar vakalarına rastlanabiliyor. Kurumsal olarak bakıldığında işten ayrılma sonucunda çalışan sayısında azalma, müşteri şikâyetlerinde artış, şirket cirosunda azalma gibi durumlarla karşı karşıya kalabiliyor.

Bu araştırmamızda, Eskişehir'de faaliyet gösteren beyaz eşya-elektronik, giyim, yiyecek ve perakende sektörü çalışanlarının tükenmişlik düzeyleri arasındaki ilişki saptanmış, anket tekniği kullanarak gerçekleştirilen araştırma ile problemler incelenmiş, elde edilen veriler değerlendirilerek, konuyla ilgili çözümler geliştirilmeye çalışılmıştır.

\section{TÜKENMIŞLIK KAVRAMI}

Modern çağın sendromları arasında yer alan tükenmişlik kavramı 1961 yılında yayınlanan Greene' nin “Bir Tükenmişlik Olayı" romanında psikolojik açıdan çöküntüye uğramış bir mimarın işini bırakıp Afrika ormanlarına kaçışıyla gündeme gelmiştir(Taştan, N. O., 2015, s.,18). Tükenmişlik kavramı, yoğun ve yüz yüze insan ilişkilerini gerektiren sağlık çalışanlarında incelenmeye başlanmış daha sonra öğretmenlik, polislik, yöneticilik gibi benzer etkileşim gerektiren meslek gruplarında da araştırma konusu olmuştur(Çavuşoğlu, í., 2009, s., 13; Gündüz, B., 2004). illk kez Freudenberger tarafından "insanların aşırı çalışmaları sonucu işlerinin gereklerini yerine getiremez bir duruma gelmeleri anlamını taşıyan duygusal tükenme” olarak tanımlanmıştır. Günümüzde en çok kabul gören tanımı Maslach ve arkadaşları yapmışlardır. Bu tanıma göre tükenmişlik, "Duygusal Tükenme", "Duyarsızlaşma" ve "Kişisel Başarıda Azalma” boyutlarından oluşmaktadır. Maslach'a göre tükenmişlik belirtileri gösteren bireyler; hizmet verdikleri kişilerle olan ilişkileri boyunca kendilerini duygusal olarak aşırı yüklenmiş ve tükenmiş, bu kişilere karşı duyarsız ve kayıtsız davranan ve işinde başarılı ve yeterli olma duygularını göreli olarak kaybetmiş olan kişilerdir(Altay ve Akgül, 2010, s., 88-89)

\section{MASLACH TÜKENMIŞLIK MODELI}

Günümüzde kabul gören en yaygın tükenmişlik tanımı, Maslach ve arkadaşları tarafından yapılan ve tükenmişliği üç boyutlu bir kavram olarak ele alan tanımdır. Bu tanımda tükenmişlik; işi gereği sürekli olarak diğer insanlarla yüz yüze çalışan kişilerde sıklıkla ortaya çıkan üç boyutlu bir sendrom olarak kabul edilmektedir. Bu boyutlar duygusal tükenme, duyarsızlaşma ve düşük kişisel başarıdır (Dönmez, 2008, s., 70). Maslach Tükenmişlik Envanterinin birinci alt ölçeği 9 maddeden (1, 2, 3, 6, 8, 13, 14, 16, 20) oluşan "Duygusal Tükenme (EmotionalExhaustion, EE)", ikincisi 5 maddeden $(5,10,11,15,22)$ oluşan "Duyarsızlaşma (Depersonalizasyon, DP)" ve üçüncüsü de 8 maddeden $(4,7,9,12,17,18,19,21)$ oluşan "Kişisel Başarı (PersonalAccomplishement, PA)" alt ölçeğidir. Bu araştırmamızda seçeneklere karşılık gelen puanlar belirlenmiştir. MBI Beşli Dereceleme Ölçeğiyle İlgili Puanlara Karşılık Gelen puanlar çizelgede verilmiştir. 
Tablo 1: Maclach Puan Aralığı

\begin{tabular}{|lcll|}
\hline Seçenekler & Puan & $\begin{array}{l}\text { Alt-Üst } \\
\text { Sınır }\end{array}$ & Puana Karşılık Gelen Yorum \\
\hline Hiçbir Zaman & 0.00 & $0.00-0.79$ & Çok Az Tükenmiş \\
\hline Çok Nadir & 1.00 & $0.80-1.59$ & Az Tükenmiş \\
\hline Bazen & 2.00 & $1.60-2.39$ & Orta Düzeyde Tükenmiş \\
\hline Çoğu Zaman & 3.00 & $2.40-3.19$ & Çoğunlukla Tükenmiş \\
\hline Her Zaman & 4.00 & $3.20-4.00$ & Çok Fazla Tükenmiş \\
\hline
\end{tabular}

Kaynak: (Yılmaz, 2007: 89-90).

MBI ile tükenmişlik üzerine araştırmacılar birçok çalışma yapmışlardır. MBI üzerine sağılı çalışanlarıyla ilgili; Beemsterbooer (1984), Çam (2001), Yaman ve Ungan (2002), Ünal vd. (2001), Akbolat ve Işık (2008), Aras (2006), öğretmenler ve akademisyenler üzerine; Cherniss (1988), Dworkin vd.(1986), Daly (1992), Ackerley vd. (1988), Pines (2002), Hock (1988),Yavaş (2007), Deliorman vd. (2009), Özdemir (2001), Tümkaya vd. (2009), Whitaker (1996), Izgar (2001), Yılmaz (2007), banka çalışanları üzerine; Yıldırım (1996), Sılığ (2003), Apak ve Tavşancı (2008), Uysal (2007), otel çalışanları üzerine; Tepeci (2003), Altay (2009), Anastasios vd. (2010), Buıck vd. (2001) bu örneklerden bazılarıdır.

\section{ARAŞTIRMANIN AMACI, YÖNTEMI, KAPSAMI VE SINIRLILIKLARI}

Bu araştırmanın amacı tükenmişlik sendromuna sıklıkla yakalanan hizmet sektörü çalışanlarının tükenmişliğini, $\mathrm{MBI}$ envanterine göre ölçmektir. Araştırmada anket yöntemi kullanılmıştır. Anketin kapsamı beyaz eşyaelektronik, giyim, yiyecek ve diğer perakende sektörü çalışanlarının duygusal, fiziksel, ruhsal durumlarını ve bu durumlarla demografik faktörlerin ilişkisini araştırmaktır. Araştırma Eskişehir ilinde hizmet sektöründe çalışan 720 kişi ile sınırlıdır. Araştırmada frekanslar, t, F ve regresyon analizlerinin sonuçları yorumlanmıştır.

Araştırmada kullandığımız Maslach Tükenmişlik Envanteri ve alt boyutlarının güvenilirlik analizleri ise Cronbach alfa ile test edilmiştir. Maslach Tükenmişlik Envanteri ve alt boyutlara ilişkin Cronbach Güvenilirlik Katsayısı hesaplanmıştır. Maslach tükenmişlik ifadelerinin güvenilirlik katsayısı 0,926 ile duygusal tükenme 0,906'nin yüksek derecede güvenilir bir ölçek olduğu, duyarsızlaşma 0,768 ile oldukça güvenilir bir ölçek, kişisel başarı ise 0,876 ile mevcut durumu yansıtmadaki güvenilirliği ise yüksek derecede güvenilir bir ölçektir. (Kalaycı, 2005, s., 403).

Tablo 2: Maslach DT, D, KB Ortalama ve Standart Sapma Değerleri

\begin{tabular}{|l|c|c|c|}
\hline & Duygusal Tükenme & Duyarsızlaşma & Kişisel Başarı \\
\hline Ortalama & 2,6349 & 2,4331 & 1,8274 \\
\hline Standart Sapma & 1,49056 & 1,35989 & 0,99479 \\
\hline Değer & 720 & 720 & 720 \\
\hline
\end{tabular}

Tablo 2 incelendiğinde tükenmişliğin alt boyutu olan duygusal tükenme ortalaması hizmet çalışanlarının $(2,6349)$ ile en yüksektir ve çoğunlukla tükenmişliği ifade eder. Duyarsızlaşma açısından, duygusal tükenmeye göre duyarsızlaşma puanında $(2,4331)$ düşme görülmekle beraber çoğunlukla tükenmişliği ifade eder. Tükenmişliğin kişisel başarı alt boyutunda $(1,8274)$ puanı kişisel başarının orta düzeyde olduğunu ve orta düzeyde tükenmişliği ifade etmektedir. 
Tablo 3: Demografik Özelliklerin Frekans ve Yüzde Dağılımları

\begin{tabular}{|c|c|c|c|c|c|}
\hline \multicolumn{6}{|c|}{ Sektörün Frekans ve Yüzde Dağılımları } \\
\hline & Elektronik ve beyaz eşya & Giyim & $\begin{array}{l}\text { Hızlı tüketim- } \\
\text { yiyecek-içecek }\end{array}$ & Perakendecilik & Toplam \\
\hline Frekans & 168 & 266 & 177 & 109 & 720 \\
\hline Yüzde & 23,3 & 36,9 & 24,6 & 15,1 & 100,0 \\
\hline \multicolumn{6}{|c|}{ Statünün Frekans ve Yüzde Dağılımları } \\
\hline & Müdür/müdüryrd. & Satış sorumlusu & Kasiyer & Diğer & \\
\hline Frekans & 187 & 227 & 141 & 165 & 720 \\
\hline Yüzde & 26 & 31,5 & 19,6 & 22,9 & 100.0 \\
\hline \multicolumn{6}{|c|}{ Eğitimin Frekans ve Yüzde Dağılımları } \\
\hline & İlkokul mezunu & Ortaokul mezunu & Lise mezunu & Üniversite mezunu & \\
\hline Frekans & 26 & 78 & 318 & 298 & 720 \\
\hline Yüzde & 3,6 & 10,8 & 44,2 & 41,4 & 100.0 \\
\hline
\end{tabular}

Tablo 3'de sektör olarak incelendiğinde giyim sektörünün \%36,9 ile en fazla olduğu görülmektedir. Bunu \%24,6 ile hızlı tüketim-yiyecek-içecek, \%23,3 ile elektronik ve beyaz eşya takip etmektedir. Perakendecilik sektörünün oranı ise \%15,1 ile en düşüktür. Katılımcılar statülerine göre incelendiğinde \%31,5 ile Satış sorumlusu oranı en fazladır. Bunu \%26 ile müdür/ müdür yardımcıları, \%22,9 ile diğer statüler takip etmektedir. Kasiyerlerin oranı ise \%19,6 ile en düşüktür. Çalışanların eğitim durumu incelendiğinde lise mezunlarının \%44,2 ile en fazladır. Lise mezunlarını \%41,4 ile Üniversite mezunları, \%10,8 ortaokul mezunları takip etmektedir. İlkokul mezunlarının oranı ise \%3,6 ile en düşüktür.

Tablo 4: Hizmet Sektörü Çalışanlarının Cinsiyet Değişkenine Göre t-Testi İle Tükenmişlik Düzeylerinin Karşılaştırılması

\begin{tabular}{|c|c|c|c|c|c|c|c|c|}
\hline \multicolumn{8}{|c|}{ Varyans Eşitliği İçin Levene Testi } \\
\hline & Cinsiyet & Frekans & Ortalama & Standart sapma & $\mathbf{F}$ & $\mathbf{p}$ & $\mathbf{t}$ & $\mathbf{p}$ \\
\hline \multirow{2}{*}{ D } & Kadın & 375 & 2,4283 & 1,43402 & 5,062 & 0,025 & $-0,098$ & 0,922 \\
& Erkek & 345 & 2,4383 & 1,27650 & & & & \\
\hline \multirow{2}{*}{ DT } & Kadın & 375 & 2,6809 & 1,58856 & 3,252 & 0,072 & 0,863 & 0,388 \\
\cline { 2 - 7 } & Erkek & 345 & 2,5849 & 1,37670 & & & & \\
\hline \multirow{2}{*}{ KB } & Kadın & 375 & 1,8527 & 1,01992 & 1,055 & 0,305 & 0,709 & 0,478 \\
\cline { 2 - 6 } & Erkek & 345 & 1,8000 &, 96747 & & & & \\
\hline
\end{tabular}

$\mathbf{H}_{0}$ : Tükenmişlik alt ölçekleri ile cinsiyet değişkeni arasında arasına anlamlı ilişki yoktur.

$\mathbf{H}_{\mathbf{1}}$ : Tükenmişlik alt ölçekleri ile cinsiyet değişkeni arasında arasına anlamlı ilişki vardır. 
Bu analizde erkek, bayan çalışanların D, DT ve KB düzeyleri arasında anlamlı bir fark olup olmadığı sorgulanmaktadır. Analiz sonuçlarına bakıldığında D, DT ve KB’nin olasılık düzeyleri, \%5 anlamlılık düzeyinden büyük olduğundan sıfır hipotezi kabul edilir. Bu durumda cinsiyetle tükenmişlik alt ölçekleri arasına anlamlı bir ilişki yoktur.

Tablo 5: Hizmet Sektörü Çalışanlarının Yaş Değişkeni ile Tükenmişlik Ölçeğinin Alt Boyutlarına ilişkin Anova Sonuçları

\begin{tabular}{|c|c|c|c|c|c|c|}
\hline B.D & Varyans Kaynakları & Kareler Toplamı & Sd & Kareler Ortalaması & $\mathbf{F}$ & p \\
\hline DT & $\begin{array}{l}\text { Gruplararası } \\
\text { Gruplariçi } \\
\text { Toplam }\end{array}$ & $\begin{array}{c}21,206 \\
1576,239 \\
1597,445\end{array}$ & $\begin{array}{c}3 \\
716 \\
719\end{array}$ & $\begin{array}{l}7,069 \\
2,201\end{array}$ & 3,211 & 0,023 \\
\hline D & $\begin{array}{l}\text { Gruplararası } \\
\text { Gruplariçi } \\
\text { Toplam }\end{array}$ & $\begin{array}{c}33,365 \\
1296,288 \\
1329,653\end{array}$ & $\begin{array}{c}3 \\
716 \\
719\end{array}$ & $\begin{array}{c}11,122 \\
1,810\end{array}$ & 6,143 & 0,0001 \\
\hline KB & $\begin{array}{l}\text { Gruplararası } \\
\text { Gruplariçi } \\
\text { Toplam }\end{array}$ & $\begin{array}{c}10,273 \\
701,254 \\
711,527\end{array}$ & $\begin{array}{c}3 \\
716 \\
719\end{array}$ & $\begin{array}{l}3,424 \\
0,979\end{array}$ & 3,496 & 0,015 \\
\hline
\end{tabular}

$\mathbf{H}_{0}$ :Tükenmişlik alt ölçekleri ile yaş değişkeni arasında arasına anlamlı bir ilişki yoktur.

$\mathbf{H}_{1}$ :Tükenmişlik alt ölçekleri ile yaş değişkeni arasında arasına anlamlı bir ilişki vardır.

Tablo 5'e göre, ANOVA tablosundan DT, D ve KB'nin olasılık düzeyleri, anlamlılık düzeyinden $(p<\alpha)$ küçük olduğundan $\mathrm{H}_{0}$ hipotezi reddedilir. DT, $D$ ve $K B$ için $H_{1}$ hipotezi kabul edilir. Anlamlı farklılığa sebep olan grupların hangisi olduğu varyansların homojen olup olmaması durumuna göre Post - Hoc sınamaları ile incelenmiştir. Buna göre yapılan Tukey sınaması sonucuna göre özellikle 17-20 yaş grubu haricindeki yaşlar arasında anlamlı bir farklılık bulunmaktadır.

Tablo 6: Hizmet Sektörü Çalışanlarının Gelir Değişkeni İle Tükenmişlik Ölçeğinin Alt Boyutlarına ilişkin Anova Sonuçları

\begin{tabular}{|l|l|c|c|c|c|c|}
\hline B.D & Varyans & Kareler Toplamı & Sd & Kareler Ortalaması & F & p \\
& Kaynakları & 100,842 & 3 & 33,614 & 16,081 & 0,0001 \\
\hline DT & Gruplararası & 1496,604 & 716 & 2,090 & & \\
& Gruplariçi & 1597,445 & 719 & & & \\
& Toplam & 1288,212 & 3 & 13,814 & 7,678 & 0,0001 \\
\hline D & Gruplararası & 1329,653 & 716 & 1,799 & & \\
& Gruplariçi & 76,302 & 719 & & 28,668 & 0,0001 \\
& Toplam & 76,302 & 3 & 25,434 & & \\
\hline
\end{tabular}

$\mathbf{H}_{0}$ :Tükenmişlik alt ölçekleri ile gelir değişkeni arasında arasına anlamlı bir ilişki yoktur.

$\mathbf{H}_{1}$ :Tükenmişlik alt ölçekleri ile gelir değişkeni arasında arasına anlamlı bir ilişki vardır.

Tablo 6'da görüldüğü gibi, ANOVA tablosundan DT, D ve KB olasılık düzeyleri, anlamlılık düzeyinden $(p<\alpha)$ küçük olduğundan $\mathrm{H}_{0}$ hipotezi reddedilir ve $\mathrm{H}_{1}$ kabul edilir. Buna göre Post - Hoc sınamaları sonucunda ise 5000TL ve üstü gelir elde edenlerle, 5000TL altında gelire sahip olan üç grup (1000TL altındaki, 1000-2500TL, 2500-5000TL) arasında anlamlı farklılık vardır. 
Tablo 7: Hizmet Sektörü Çalışanlarının Eğitim Değişkeni Ille Tükenmişlik Ölçeğinin Alt Boyutlarına iliş̧kin Anova Sonuçları

\begin{tabular}{|l|l|c|c|c|c|c|}
\hline B.D & Varyans Kaynakları & Kareler Toplamı & sd & Kareler Ortalaması & F & p \\
\hline & Gruplararası & 130,130 & 3 & 43,377 & 21,166 & 0,0001 \\
& Gruplariçi & 1467,316 & 716 & 2,049 & & \\
\hline D & Toplam & 1597,445 & 719 & & 15,014 & 0,0001 \\
& Gruplararası & 78,697 & 3 & 26,232 & & \\
\hline KB & Toplam & 1250,956 & 716 & 1,747 & & \\
& Gruplararasi & 1329,653 & 719 & & 26,197 & 0,0001 \\
\hline
\end{tabular}

$\mathbf{H}_{0}$ :Tükenmişlik alt ölçekleri ile eğitim değişkeni arasında arasına anlamlı bir ilişki yoktur.

$\mathbf{H}_{1}$ :Tükenmişlik alt ölçekleri ile eğitim değişkeni arasında arasına anlamlı bir ilişki vardır.

Tablo 7'de ki ANOVA tablosundan da görüldüğü gibi DT, D ve KB'nin olasılık düzeyleri $(0,0001<0,05)$ anlamlılık düzeyinden küçük olduğundan $\mathrm{H}_{1}$ hipotezi kabul edilir. Tukey sınaması sonucunda ise, anlamlı farklılığa yol açan grupların ilköğretim-ortaöğretim ve üniversite mezunları arasında olduğu görülmektedir.

Tablo 8: Hizmet Sektörü Çalışanlarının Medeni Durum Değişkeni ille Tükenmişlik Ölçeğinin Alt Boyutlarına iliş̧kin Anova Sonuçları

\begin{tabular}{|l|l|c|c|c|c|c|}
\hline B.D & Varyans Kaynakları & Kareler Toplamı & Sd & Kareler Ortalaması & F & p \\
\hline DT & Gruplararası & 21,228 & 3 & 7,076 & 3,214 & 0,022 \\
& Gruplariçi & 1576,217 & 716 & 2,201 & & \\
& Toplam & 1597,445 & 719 & & 2,032 & 0,108 \\
\hline D & Gruplararası & 11,225 & 3 & 3,742 & & \\
& Gruplariçi & 1318,428 & 716 & 1,841 & & 0,679 \\
& Toplam & 1329,653 & 719 & & 0,505 & \\
\hline KB & Gruplararası & 1,503 & 3 & 0,501 & & \\
& Gruplariçi & 710,024 & 716 & 0,992 & & \\
& Toplam & 711,527 & 719 & & & \\
\hline
\end{tabular}

$\mathbf{H}_{0}$ :Tükenmişlik alt ölçekleri ile medeni durum değişkeni arasında arasına anlamlı bir ilişki yoktur.

$\mathbf{H}_{1}$ :Tükenmişlik alt ölçekleri ile medeni durum değişkeni arasında arasına anlamlı bir ilişki vardır.

Tablo 8'de DT'nin olasılık düzeyinin $(0,022<0,05)$ anlamlılık düzeyinden küçük olduğu görülmektedir. Buna göre Tukey sınaması sonucunda bekâr ve boşanmış çalışanlar arasında anlamlı bir farklılık bulunmaktadır. 
Tablo 9: Hizmet Sektörü Çalışanlarının Çalışma Pozisyon Değişkeni ille Tükenmişlik Ölçeğinin Alt Boyutlarına ilişkin Anova Sonuçları

\begin{tabular}{|c|c|c|c|c|c|c|}
\hline B.D & Varyans Kaynakları & Kareler Toplamı & Sd & Kareler Ortalaması & $\mathbf{F}$ & p \\
\hline DT & $\begin{array}{l}\text { Gruplararası } \\
\text { Gruplariçi } \\
\text { Toplam }\end{array}$ & $\begin{array}{c}41,866 \\
1555,579 \\
1597,445 \\
\end{array}$ & $\begin{array}{c}3 \\
716 \\
719 \\
\end{array}$ & $\begin{array}{c}13,955 \\
2,173\end{array}$ & 6,423 & 0,0001 \\
\hline D & $\begin{array}{l}\text { Gruplararası } \\
\text { Gruplariçi } \\
\text { Toplam }\end{array}$ & $\begin{array}{c}27,544 \\
1302,109 \\
1329,653 \\
\end{array}$ & $\begin{array}{c}3 \\
716 \\
719 \\
\end{array}$ & $\begin{array}{l}9,181 \\
1,819\end{array}$ & 5,049 & 0,002 \\
\hline KB & $\begin{array}{l}\text { Gruplararası } \\
\text { Gruplariçi } \\
\text { Toplam }\end{array}$ & $\begin{array}{c}45,524 \\
666,003 \\
711,527 \\
\end{array}$ & $\begin{array}{c}3 \\
716 \\
719 \\
\end{array}$ & $\begin{array}{c}15,175 \\
0,930\end{array}$ & 16,314 & 0,0001 \\
\hline
\end{tabular}

$\mathbf{H}_{0}$ :Tükenmişlik alt ölçekleri ile pozisyon değişkeni arasında arasına anlamlı bir ilişki yoktur.

$\mathbf{H}_{1}$ :Tükenmişlik alt ölçekleri ile pozisyon değişkeni arasında arasına anlamlı bir ilişki vardır.

Tablo 9'a göre, olasılık düzeylerinin DT için 0,0001, D için 0,002 ve KB için 0,0001 olduğu görülmektedir. Bu değer 0,05 'den küçük olduğundan $\mathrm{H}_{0}$ hipotezi reddedilir ve $\mathrm{H}_{1}$ hipotezi kabul edilir. Buna göre Tukey sınaması sonucunda reyon müdürü ile satış danışmanı, kasiyer ve diğer çalışanlar arasında anlamlı bir farklılık bulunmaktadır.

Tablo 10: Hizmet Sektörü Çalışanlarının Çalışma Süresi Değişkeni Ile Tükenmişlik Ölçeğinin Alt Boyutlarına İlişkin Anova Sonuçları

\begin{tabular}{|l|l|c|c|r|r|c|}
\hline B.D & Varyans Kaynakları & Kareler Toplamı & Sd & Kareler Ortalaması & F & p \\
\hline DT & Gruplararası & 91,477 & 3 & 30,492 & 6,423 & 0,0001 \\
& Gruplariçi & 1505,968 & 716 & 2,103 & & \\
& Toplam & 1597,445 & 719 & & & \\
\hline D & Gruplararası & 80,088 & 3 & & & \\
& Gruplariçi & 1249,565 & 716 & 1,745 & & \\
& Toplam & 1329,653 & 719 & & & \\
\hline KB & Gruplararası & 16,864 & 3 & & 5,0001 \\
& Gruplariçi & 694,663 & 716 & & 16,314 & 0,001 \\
& Toplam & 711,527 & 719 & & & \\
\hline
\end{tabular}

$\mathbf{H}_{0}$ :Tükenmişlik alt ölçekleri ile çalışma süresi değişkeni arasında arasına anlamlı bir ilişki yoktur.

$\mathbf{H}_{1}$ :Tükenmişlik alt ölçekleri ile çalışma süresi değişkeni arasında arasına anlamlı bir ilişki vardır.

Tablo 10'dan da görüldüğü gibi, tükenmişlik alt ölçeklerinin olasılık düzeyleri DT için 0,0001, D için 0,002 ve KB için 0,001'dir. Bu değerler 0,05 anlamlılık düzeyinden küçük olduğundan $\mathrm{H}_{0}$ hipotezi reddedilir. İncelenen Tukey sınaması sonucunda ise, 0-1 yıl arası çalışanlar haricinde 8 ve üzeri yıl çalışanlar ile 2-4 ve 5-7 yıl arası çalışanlar arasında anlamlı bir farklılık bulunmaktadır.

Tablo 11: Hizmet Sektörü Çalışanlarının Sektörler Değişkeni ỉle Tükenmişlik Ölçeğinin Alt Boyutlarına iliş̧kin Anova Sonuçları

\begin{tabular}{|l|l|c|c|c|c|c|}
\hline B.D & Varyans Kaynakları & Kareler Toplamı & Sd & Kareler Ortalaması & F & p \\
\hline DT & Gruplararası & 2,675 & 3 & 0,892 & 0,400 & 0,753 \\
& Gruplariçi & 1594,770 & 716 & 2,227 & & \\
& Toplam & 1597,445 & 719 & & 1,185 & 0,315 \\
\hline D & Gruplararası & 6,567 & 3 & 2,189 & & \\
& Gruplariçi & 1323,087 & 716 & 1,848 & & 0,143 \\
& Toplam & 1329,653 & 719 & & 1,816 & 0 \\
\hline KB & Gruplararası & 5,375 & 3 & 1,792 & & \\
\hline
\end{tabular}




\begin{tabular}{|l|l|l|l|l|l|l|}
\hline & Gruplariçi & 706,152 & 716 & 0,986 & & \\
& Toplam & 711,527 & 719 & & & \\
\hline
\end{tabular}

$\mathbf{H}_{0}$ :Tükenmişlik alt ölçekleri ile sektörler değişkeni arasında anlamlı bir ilişki yoktur.

$\mathbf{H}_{1}$ :Tükenmişlik alt ölçekleri ile sektörler değişkeni arasında anlamlı bir ilişki vardır.

Tablo 11'deki sonuçlara göre; Sektörler açısından tükenmişlik durumları arasında anlamlı bir farklılık yoktur.

Tükenmişliğin alt boyutlarını hangi değişkenlerin açıkladığı çoklu regresyon analiziyle incelenmiştir. Elde edilen sonuçları aşağıdaki gibidir:

Tablo 12: Duygusal Tükenmişlik Boyutunun Stepwise Çoklu Regresyonla Analizi

\begin{tabular}{|l|c|c|c|c|c|}
\hline Model & B & Std. Sapma & Beta & t & p \\
\hline (Sabit) & 3,577 & 0,260 & & 13,747 & 0,0001 \\
\hline Eğitim Durumu & $-0,288$ & 0,077 & $-0,151$ & $-3,724$ & 0,0001 \\
\hline Kaç Yıldır & 0,411 & 0,058 & 0,270 & 7,105 & 0,0001 \\
\hline Gelir & $-0,341$ & 0,066 & $-0,220$ & $-5,170$ & 0,0001 \\
\hline
\end{tabular}

Regresyon analizi sonucunda, DT değişkenini açıklayan değişkenler olarak eğitim durumu, çalışma süresi ve gelir değişkeni olduğu görülmektedir. Eğitim durumu ve gelir değişkeni bir birim değişmesi DT değişkenini azaltır iken çalışma süresi ise DT'yi arttırmaktadır.

Tablo 13:Duyarsızlaşma Tükenmişlik Boyutu Üzerinde Stepwise Çoklu Regresyonla Analizi

\begin{tabular}{|l|c|c|c|c|c|}
\hline Model & B & Std. Sapma & Beta & t & p \\
\hline (Sabit) & 2,756 & 0,245 & & 11,273 & 0,0001 \\
\hline Kaç Yıldır & 0,357 & 0,054 & 0,256 & 6,563 & 0,0001 \\
\hline Gelir & $-0,182$ & 0,062 & $-0,129$ & $-2,941$ & 0,003 \\
\hline Eğitim Durumu & $-0,195$ & 0,073 & $-0,112$ & $-2,682$ & 0,007 \\
\hline
\end{tabular}

Regresyon analizi sonucunda, D değişkeni açıklayan değişkenler olarak eğitim durumu, çalışma süresi ve gelir değişkeni olduğu görülmektedir. Eğitim durumu ve gelir değişkeni bir birim değişmesi $D$ değişkenini azaltır iken çalışma süresi ise arttırmaktadır.

Tablo 14: Kişisel Başarı Tükenmişlik Boyutu Üzerinde Stepwise Çoklu Regresyonla Analizi

\begin{tabular}{|l|c|c|c|c|c|}
\hline Model & B & Std. Sapma & Beta & t & p \\
\hline (Sabit) & 2,546 & 0,218 & & 11,704 & 0,0001 \\
\hline Eğitim Durumu & $-0,206$ & 0,052 & $-0,162$ & $-3,943$ & 0,0001 \\
\hline Gelir & $-0,214$ & 0,045 & $-0,207$ & $-4,735$ & 0,0001 \\
\hline Kaç Yıldır & 0,147 & 0,039 & 0,144 & 3,769 & 0,0001 \\
\hline Pozisyon & 0,088 & 0,033 & 0,098 & 2,649 & 0,008 \\
\hline
\end{tabular}

Tablo 14'deki Regresyon analizi sonucuna göre, KB değişkeni açıklayan değişkenler olarak eğitim durumu, çalışma süresi, gelir değişkeni ve pozisyon olduğu görülmektedir. Eğitim durumu ve gelir değişkeni bir birim değişmesi KB değişkenini azaltır iken çalışma süresi ve pozisyon ise arttırmaktadır.

\section{SONUÇ}

Hizmet sektöründe çalışma temposunun yüksekliği, iş saatlerindeki değişkenlik, uzun ve sürekli mesailer, dini, resmi bayram ve özel günlerde çalışma zorunluluğu, genel anlamda belirsizlik hissi ve sadece yönetici pozisyonundaki çalışanların yüksek maaş alması (örneğin bazı işletmelerde asgari ücret zammında, yeni gelenler 1300 ile işe başlarken, 1400 ile çalışanlara zam yapılmamıştır) yıllarca emek verdiği kurumda belli bir pozisyona gelememe, kendi isteği ile işten ayrılması durumunda tazminatını alamaması, sürekli ayakta ve günde 8 ile 12 saat arasında çalışma, çok az çalışanla kurumun işletilmeye çalışılması, müşterilerin kötü davranışlarına maruz kalma gibi nedenler, çalışanları, meslekten bıkma, çabuk yıpranma gibi durumlarla karşı karşıya bırakmaktadır. 
Bu araştırmada, Eskişehir'de hizmet veren beyaz eşya, elektronik, giyim, yiyecek-içecek ve diğer perakende sektörlerinde çalışan iş görenlerin, tükenmişlik durumları incelenmiştir.

Maslach Tükenmişlik Ölçeği'nden yararlanılarak hazırlanan anketin demografik özellikler kısmında: araştırmaya $345^{\prime} i$ bay ve 375'i bayan olmak üzere toplam 720 kişi katılmıştır. Eskişehir'de faaliyet gösteren hizmet çalışanlarının mesleki tükenmişlik düzeyleri ile işe bağlııkları arasındaki ilişkiyi belirlemek üzere yapılan saha araştırmasından elde edilen bulgular ışığında aşağıdaki sonuçlar elde edilmiştir:

- Cinsiyetle tükenmişlik alt ölçekleri arasına anlamlı bir ilişkinin olmadığı ortaya çıkmıştır. Erkek ve bayan çalışanlar cinsiyet bakımından aynı etkiye maruz kalmaktadır.

- 17-20 yaş grubu haricindeki çalışanlar arasında anlamlı farklılıklar bulunmuştur. 17-20 yaş arası gençlerin işe olan bağlııkları ve bakış açısı, 20 yaş üzeri olan çalışanlarla farklı olması bu gençlerin öğrenim hayatının devam etmesi, yarı zamanlı çalışıp okul harçlıklarını çıkarması, erkeklerin askerlik öncesi geçici iş olarak bakmasından kaynaklandığı düşünülmektedir.

- Ağırlıklı olarak 2500-5000+ maaş geliri olanlarla daha düşük geliri olanlar arasında her üç alt boyutta da anlamlı farklılıklar bulunmaktadır. Asgari ücretin daha yeni 1300 TL olduğu düşünüldüğünde Türkiye şartlarında 2500-5000+ ücretin çalışanlar için cazip olduğu düşünülmektedir.

- Illköğretim, ortaöğretim ve üniversite mezunları arasında her üç boyutta da anlamlı bir farklılıklar bulunmaktadır. Illköğretim ve ortaöğretim mezunlarının işçi sınıfında daha fazla mesai ve daha az maaş, üniversite mezunlarının yönetici pozisyonunda olup daha yüksek maaş almasının bu farklılığa yol açtığı düşünülmektedir.

- Bekâr ve boşanmış çalışanlar arasında anlamlı farklılıklar bulunmaktadır.

- Reyon müdürü ile satış danışmanı, kasiyer ve diğer çalışanlar arasında anlamlı bir farklılıklar bulunmaktadır.

- 8 ve üzeri yıl çalışanlar ile 2-4ve 5-7 yıl arası çalışanlar arasında anlamlı bir farklılıklar bulunmaktadır. Hizmet sektörü çalışanları ayakta, yüz yüze ve birebir insanlarla ilgilendiğinden 8 yıl çalışma bu çalışmamızda kritik eşik olarak görülmektedir. Özellikle işletme sahipleri bu hususu dikkatle incelemeli gerekli çalışma koşullarını düzeltmelidir.

- Hizmet sektörler açısından tükenmişlik durumları arasında anlamalı bir farklılık yoktur.

- Eğitim durumu ve gelir değişkeni bir birim değişmesi DT değişkenini azaltırken çalışma süresini ise arttırmaktadır.

- Eğitim durumu ve gelir değişkeni bir birim değişmesi D değişkenini azaltır iken çalışma süresi ise arttırmaktadır.

- Eğitim durumu ve gelir değişkeni bir birim değişmesi KB değişkenini azaltırken çalışma süresi ve pozisyon ise arttırmaktadır.

- Psikolojik ve örgütsel davranış alanlara konu olan tükenmişlik, çalışanlar ve örgütler açısından önemli etkiler ve sonuçlar doğurmaktadır. Hizmet sektörü dışında tükenmişlik yaşayan iş görenler, hata yapma, bazı işleri erteleme, işe geç gelme, izinsiz olarak ya da hastalık nedeni ile işe gelmeme gibi sorunlarla karşılaşmaktadır. Diğer taraftan hizmet sektöründe bazı işletmelerde çalışan sayısının çok az olması, hizmetin niteliğinde bozulma, iş ve iş dışındaki ilişkilerde bozulma, meslektaşlarına ve hizmet verdiği kişilere karşı ilgisiz tavırlar gösterme, işle ilgilenmek yerine başka şeylerle vakit geçirme, kuruma olan ilginin kaybı vb. nedenler tükenmişliğin çalışma hayatına ve dolayısıyla kuruma olan olumsuz etkileridir. Müşteriler sorunlarını çözememektedir. Örneğin B süpermarketinde çalışan sayısı 10 ise işletme sahibi bunu ikiye ya da üçe bölerek kullanmakta böylece hem çalışanına izin kullandırmakta hem de az çalışanla işi çevirmektedir. Sıklıkla müşteriler bir şeyler sormak için çalışan aramakta, tabi bulamamaktadır. (Özellikle isim yapmış marketlerde müşteriler sorunlarını iletmek için mağaza içinde dolaşarak çalışan aramakta tepki göstererek en son kasaya gelerek kasiyere sormaktadır). Bu sektörde çalışanların sömürülmesi devam etmektedir. Çalışan işinden ayrılmaya kalksa tazminatı yanacak, çalışmaya devam etse 12 saate yakın çalışma, değişken izin günleri(dini bayramlarda 
bile tam izin kullanmama), düşük maaş, ağır iş yükü, kendine ve ailesine vakit ayıramama, değersizlik hissi vb gibi nedenler çalışanı işinden soğutmakta ve genellikle istifayla sonuçlanmaktadır.

Bu sonuçlarla karşılaşmadan önce önlemler alabilmek önemlidir. Ancak tükenmişlik sorunu yaşanmaya başlandıysa bunu yaşıyorken anlayabilmek ve ona uygun çözümler üretebilmek tükenmişliğe engel olmayı sağlayabilir. Mesleki tükenmişliğe engel olabilmek için bireyin kendisine yapacağı müdahaleler, kurum bazında yapılabilecek düzeltme veya düzenlemeler gerekmektedir.

Bu araştırma, Eskişehir'de faaliyet gösteren, hizmet sektörü iş görenleri üzerinde gerçekleştirilmiştir. Bu doğrultuda, gerek araştırmanın yapıldığı sektörlerin, çeşitli nedenlerle (zaman, maliyet vb.) kapsama dâhil edilemeyen şubelerinde, daha ayrıntıı araştırmaların yapılması, bu tür çalışmaların genelleme oranını artııır ve yapılacak araştırmalar arasında karşılaştırma yapma imkânı vermesi açısından, iş görenler ve işletmeler açısından faydalı olacaktır.

\section{KAYNAKÇA}

Ackerley, G. D., Burnell, J. , Holder, C.ve Kurdek, L., (1988), "Burnout Amang Licensed Psychologists", Professional Psychology: Research and Practise, 19, 6624-631.

Akbolat, M., ve Işık, O., (2008), Sağlık Çalışanlarının Tükenmişlik Düzeyleri: Bir Kamu Hastanesi Örneği, Hacettepe Sağlık İdaresi Dergisi, Cilt:11, Sayı:2. S., $229-254$.

Altay, H. (2009). Antakya ve İskenderun otel çalışanların tükenmişliği ve iş tatmini üzerine bir araştırma. Mustafa Kemal Üniversitesi Sosyal Bilimler Enstitüsü Dergisi, 6, 11, 85-108.

Altay,H., Akgül V., (2010), Seyahat Acentaları Çalışanlarının Tükenmişlik Düzeyi: Hatay Örneği, Mustafa Kemal Üniversitesi Sosyal Bilimler Enstitüsü Dergisi , Cilt (7) ,Sayı: 14, $87-112$.

Anastasios, Z., Panayiotis, C. And Iphigenia P., (2010)., Investigating The Association Of Burnout And Personality Traits Of Hotel Managers, International CHRIE Conference-Refereed Track, Event 11.

Apak, S. ve Tavşancı,A., (2008), Türkiye'de Yabancı Bankacılığın Gelişimi ve Ekonomi Politikaları İle Uyumu, Maliye Finans Yazıları, 22, 80, 3353

Aras, Z., (2006). Birinci Basamak Sağlık Kurumlarında Çalışan Hemşire ve Ebelerin Tükenmişlik Durumları, Yüksek Lisans Tezi, Marmara Üniversitesi Sağlık Bilimleri Enstitüsü

Beemsterboer, J. ve Baum B. H., (1984), "Burnout: Definition and Health Care Manegement", Social Work in Healt Care, 10, 1, 97-110.

Buick, I. ve Thomas, M., (2001), “Why Do Middle Managers In Hotels Burnout?”, International Journel of Contemporary Hospitality Management, 13, 6, 304-309.

Cherniss, C., (1988), “Observed supervisior Behaivior and Teacher Burnout in Special Education”, Exceptional Children, 54(5), 449-454.

Çam, O. (2001), "The Burnout in Nursing Academicians in Turkey", International Journal of Nursing Studies, 38, $201-207$.

Çavuşoğlu, İ., (2009), Sınıf Öğretmenliği Son Sınıf Öğretmen Adaylarının Tükenmişlik Düzeylerinin İncelenmesi, T.C.Çukurova Üniversitesi Sosyal Bilimler Enstitüsü Sınıf Öğretmenliği Anabilim Dalı, Yüksek Lisans Tezi (yayınlanmamış) Adana.

Daly, S., (1992), "Principal Burnout in the Public Scholls: A Study Comparing the Perceived Burnout Levels of Elementary", Dissertation Abstract International, 53(7), 2177 A.

Deliorman, R. B. ,Yıldız, S., Boz, İ. T ve Yiğit, İ. (2009), “Tükenmişliği Ölçmede Alternatif Bir Araç: Kopenhag Tükenmişlik Envanterinin Marmara Üniversitesi Akademik Personeli Üzerine Uyarlaması”, Yönetim, 20, 63, 77-98 .

Dönmez,B., (2008), Seyahat Acentasında Çalışan İş Görenlerin İş Doyumu ve Tükenmişlik Düzeyleri Arasındaki ilişki, Yüksek Lisans Tezi, , Mersin Üniversitesi, s.70.

Dworkin, A., (1986), "Teacher Burnout in the Public Schools, State University of New York Pres", Albany. (Erişim: http: // site.ebrary.com/ lib/ deulibrary/ )

Gündüz, B. (2004), “Öğretmenlerde Tükenmişliğin Akılcı Olmayan İnançlar ve Mesleki Bazı Değişkenlere Göre Yordanması”, Yayınlanmamış Doktora Tezi, Çukurova Üniversitesi Sosyal Bilimler Enstitüsü, Adana.

Hock, R., (1988),. Professional Burnout Among Public School Teachers. Public Personnel Management, 17(2), 12-16.

Izgar, H. (2001), Okul Yöneticilerinde Tükenmişlik, Nobel Yayın Dağıtım,

Kalaycı, Ş., (2005), SPSS Uygulamalı Cok Değişkenli İstatistik Teknikleri, (Editör), , Ankara: Asil Yayıncılık. 
Özdemir, H. D., (2001), Üniversite Akademik Personelinin Görev Ünvanları Açısından İ̧̧ Tükenmişlik Düzeylerinin Araştırılması, Yayınlanmamış Yüksek Lisans Tezi, Cumhuriyet Üniversitesi, Sosyal Bilimler Enstitüsü, Sivas.

Pines, A. M., (2002), Teacher Burnout: A Psychodynamic Existential Perspective.Teachers And Teaching: Theory And Practice, 8(2), 121-140

Sılığ, A., (2003), "Banka Çalışanlarının Tükenmişlik Düzeylerinin Çeşitli Değişkenler Açısından İncelenmesi”, Eskişehir Anadolu Üniversitesi Eğitim Bilimleri Enstitüsü (Yayınlanmamış Yüksek Lisans Tezi).

Taştan,N.O.,, (2015), Mobbing (Psikolojik Şiddet) Algısı, Tükenmişlik Sendromu ve İşten Ayrılma Niyeti Arasındaki ilişki: Banka Çalışanları Üzerinde Bir Araştırma, Yüksek Lisans Tezi, Beykent Üniversitesi, s.18.

Tepeci, M. ve Birdir, K., (2003), Otel Çalışanlarında Tükenmişlik Sendromu, 11. Ulusal Yönetim ve Organizasyon Kongresi Bildiriler Kitabı, 959-972.

Tümkaya, S., Çam, S. ve Çavuşoğlu, İ., (2009), "Tükenmişlik Ölçeği Kısa Versiyonu’nun Türkçe’ye Uyarlama, Geçerlik ve Güvenirlik Çalışması”, Çukurova Üniversitesi Sosyal Bilimler Enstitüsü Dergisi, c.18, S.1, ss.387-398.

Uysal, M. B., (2007), Müşteri İlişkileri Departmanında Çalışanların Tükenmişlik Düzeyleri, Yüksek Lisans Tezi,Sakarya Üniversitesi Sosyal Bilimler Enstitüsü,108s., (Yayımlanmamış)

Ünal, S., Karlıdağ, R. ve Yoloğlu, S., (2001), “Hekimlerde Tükenmişlik ve İş Doyumu Düzeylerinin Yaşam Doyumu Düzeyleri İle ilisşkisi” Klinik Psikiyatri, 4:113-118.

Whitaker, Kathryn S., (1996), “Exploring Causes Of Principal Burnout”, Journal Of Educational Administration, 34, 1, 60-71.

Yaman,H., \& Ungan,M., (2002). Aile Hekimliği Asistan Hekimleri Üzerinde Bir İnceleme, Türk Psikoloji Dergisi, 17(49) : 37-44.

Yavaş,T.,(2007), Kırsal Alanda ve Kent Merkezinde Çalışan Sınıf Öğretmenlerinin İş Doyumu, Fırat Üniversitesi Sosyal Bilimler Enstitüsü Eğitim Bilimleri Anabilim Dalı, (Yayımlanmamış Yüksek Lisans Tezi).

Yıldırım, F., (1996), “Banka Çalışanlarında İş Doyumu ve Algılanan Rol Çatışması ile Tükenmişlik Arasındaki iliş̧ki, Hacettepe Üniversitesi Sosyal Bilimler Enstitüsü (Yayınlanmamış Yüksek Lisans Tezi).

Yılmaz,A., (2007), İlköğretim Müfettişlerinin Mesleki Görevlerini Yerine Getirme Durumları İle Tükenmişlik Düzeyleri Arasındaki İlişki,Doktora Tezi, Abant İzzet Baysal Üniversitesi Sosyal Bilimler Enstitüsü, s. 246. 